\title{
Empirikus vizsgálati mód három névszói esetrag jelentéseinek elkülönítésére
}

\author{
Pomázi Bence \\ Eötvös Loránd Tudományegyetem \\ ELKH Nyelvtudományi Kutatóközpont
}

\begin{abstract}
Összefoglaló
A tanulmány egy empirikus módszert kínál három magyar névszói esetrag jelentéseinek elkülönítésére. A három vizsgált esetrag a -nak/-nek, a -hoz/-hez/-höz és a -nál/-nél, mindegyik gazdag poliszém jelentésstruktúrával rendelkezik. A vizsgálat célja az volt, hogy meg lehessen állapítani az egyes jelentéseket, mégpedig anyanyelvi beszélők intuíciói alapján. Ehhez egy előzetes korpusz alapú vizsgálat után csoportosítási feladatot végeztettem 25 anyanyelvi beszélővel, akiknek a feladata az volt, hogy a kiválasztott esetragok 20-20 előfordulásából tetszőleges csoportokat állítsanak fel a ragok jelentése alapján. Az adatokon Past szoftverrel hierarchikus klaszteranalízist végeztem, az eredmények dendrogramon ábrázolhatók. A dendrogramról leolvasható csoportok az egyes ragok jelentéseinek elrendeződéséről árulnak el sokat a poliszém jelentéshálózatban.
\end{abstract}

Kulcsszavak: poliszémia, ragpoliszémia, hierarchikus klaszteranalízis, csoportosítás

\section{Bevezetés ${ }^{1}$}

A tanulmány bemutat egy olyan empirikus vizsgálati módot a ragpoliszémia jelenségének kutatására, amelyet magyar nyelvi anyagra még nem alkalmaztak. A három vizsgált névszói esetrag a -nak/-nek, a -hoz/-hez/-höz és a -nál/-nél. Az első kettő történetileg latívuszi irányulással rendelkező esetrag, a harmadik lokatívuszi esetrag. Mindhárom esetrag poliszém jelentésstruktúrával rendelkezik, a tanulmány pedig arra a kérdésre keresi a választ, hogy az egyes jelentések elkülöníthetők-e nyelvhasználói intuíciók alapján.

A vizsgálat alapját Sandra és Rice kísérlete adja (Sandra-Rice 1995), akik angol prepozíciók jelentéshálózatát kutatták olyan módon, hogy anyanyelvi beszélőkkel végeztettek csoportosítási feladatot. A csoportosítási feladat során az adatközlők saját intuícióik segítségével jelentésbeli hasonlóság alapján csoportokat hoznak létre a nekik bemutatott nyelvi adatokból. A létrehozott csoportokból a Past

\footnotetext{
${ }^{1}$ Az Információs és Technológiai Minisztérium ÚNKP-19-3 kódszámú Új Nemzeti Kiválóság Programjának szakmai támogatásával készült. Előadásként elhangzott a Nyelvészdoktoranduszok 23. Országos Konferenciáján 2019. november 28-án. A tanulmány egy korábban, angol nyelven megjelent cikk kibővített változata: Pomázi (2019). A magyar nyelvú tanulmány nagyobb hangsúlyt fektet a jelentéshálózatok egyes kapcsolatainak bemutatására. Ennek megfelelően a csoportosítási feladat mondataiból többet bemutat, így képes rámutatni új, lehetséges strukturális és szemantikai motivációkra a csoportosítás során.
} 
szoftver ${ }^{2}$ segítségével hierarchikus klaszteranalízist végeztem, a szoftver az eredményeket dendrogramon ábrázolta. A dendrogram a tipikus együttállásokat szemlélteti. Az eredeti módszertanon bizonyos pontokon változtattam az eredmények nagyobb megbízhatósága érdekében. A tanulmány fő fókusza a -nak/-nek rag jelentésszerkezetének bemutatása az eredmények alapján, viszont a másik két raggal és a módszerrel kapcsolatban is le lehet vonni következtetéseket. A kísérlet központi kérdése az, hogy mennyire felelnek meg a nyelvhasználói gyakorlati tudáson alapuló csoportosítások a nyelvészeti szempontok alapján felállított csoportosításoknak, illetve hogy a vizsgált esetragok jelentésszerkezetében a nyelvhasználói intuíció alapján hol lehet nagyobb jelentéscsoportokat feltételezni.

A tanulmány az elméleti keret bemutatásával indít (2.), ezt követi a módszer leírása (3.). A csoportosítási feladatot megelőző korpuszvizsgálat ismertetése (3.1.) után az eredmények következnek (4.). A tanulmány összegzéssel zárul (5.).

\section{Elméleti háttér}

A kutatás elméleti háttere a funkcionális kognitív nyelvleírás (vö. pl. Tolcsvai Nagy 2013; 2017a; Langacker 1987; 2008), azon belül is a kognitív szemantika (Lakoff 1987; Johnson 1987). A kognitív szemantika kiemeli, hogy a grammatikai elemek jelentése a lexikálisabb jelentésü nyelvi elemekhez hasonlóan szerkezetes, bár a jelentésüket a lexikális elemekéhez képest kevesebb alszerkezet jellemzi; a jelentésük sematikusabb, mint a lexikális jelentésü szavaké; viszonyt konstruálnak meg, elsődlegesen főként téri viszonyt (Tolcsvai Nagy 2017b: 371).

A magyar névszói esetragokra jellemző a poliszémia. A poliszémiát a kognitív nyelvészet a kategorizációval összefüggésben vizsgálja (Lewandowska-Tomaszczyk 2007: 140), és a prototípuselvű kategorizációt érvényesíti (vö. Rosch 1973). A prototípuselvű kategorizáció alapján a kategória elemei nem egyformán jók, vannak központibb kategóriatagok, amelyek az elvont közös tulajdonságok közül többel rendelkeznek, illetve vannak periférikusabb kategóriatagok, amelyek kevesebbel. A legtöbb közös tulajdonsággal rendelkező kategóriaelem a prototípus, a többi elem pedig ehhez képest helyezkedik el közelebb vagy távolabb (Kövecses-Benczes 2010: 29).

A poliszémia jelentéskiterjesztés eredménye (Tolcsvai Nagy 2013: 235), a jelentés kiterjesztése pedig motivált (Radden-Panther 2004: 15), a kiterjesztés kognitív motivációját pedig a prototípus szolgáltatja (Lewandowska-Tomaszczyk 2007: 148). Tolcsvai Nagy Gábor (2013: 240) a következőket emeli ki a prototipikus jelentésről: a prototipikus jelentés a legközvetlenebbül megtapasztalható viszonyt konstruálja meg; ez a jelentések közül az első, amely kontextus nélkül előhívódik, illetve általában történetileg is ez az elsődleges jelentés. Ez összefügg azzal is, hogy a magyar névszói esetragok a kezdetekben leggyakrabban valamilyen helyviszonyt fejeztek ki (Korompay 1991: 299). ${ }^{3}$

A poliszémiakutatás több kérdést is felvet. Nehéz megállapítani, hogy honnantól számít egy jelentés új jelentésnek. Érdemes kontinuumot feltételezni a szemantikai

\footnotetext{
2 Elérhető: https://folk.uio.no/ohammer/past/ [utolsó letöltés: 2020. 10. 16.]

${ }^{3} \mathrm{~A}$-nak/-nek rag esetében kérdésként merül fel az is, hogy az alacsony gyakorisággal előforduló téri viszony kifejezése prototípusnak számít-e a szinkrón nyelvállapotban. A jelen tanulmány ezt a kérdést nem kívánja eldönteni.
} 
meghatározatlanság és a poliszémia között (Cuyckens-Zawada 2001: xvi). A jelentések kiterjesztése általában a konkrét $\rightarrow$ elvont irányban történik. Az esetragok általában két sematikus figura valamilyen viszonyát konstruálják meg, az új jelentés pedig létrejöhet a figurák jellegének megváltozásától, a közöttük lévő viszony megváltozásától, és annak a kognitív tartománynak a megváltozásától is, amelyben az adott viszony feldolgozható (Tolcsvai Nagy 2013: 249).

A kísérlet szempontjából is fontos, hogy az esetragok jelentését önmagukban természetesen nem lehet vizsgálni. Langacker (1987: 277) kiemeli, hogy a nyelvi elemek nem önmagukban fordulnak elő, hanem nagyobb struktúrákban, kompozitumszerkezetekben. A kompozitumszerkezetek olyan összetett jelentésszerkezetek, amelyek elemei a komponensszerkezetek, ezek közül az egyik részletezőbb jelentésű (ebben az esetben a névszói tő), a másik sematikusabb (a rag), közöttük pedig kölcsönös szemantikai viszony van. Ez azért fontos, mert az adatközlőket a csoportosítási feladat során valószínúleg befolyásolni fogja annak a névszónak a jelentése is, amelyen előfordul az adott rag, illetve tágabban az ige természete, valamint a mondat által vázolt jelenet is. Az egyes ragok jelentése tehát abban a támogató közegben, kontextusban értelmezhető, amelyben előfordulnak. A szemantikai kölcsönösség viszont azt jelenti, hogy az alaptag (leggyakrabban ige) és a szintaktikai viszonyt jelölő névszói esetrag alszerkezetei között megfelelések vannak, tehát nem elég pusztán az alaptag megváltoztatásának betudni az újabb funkció megjelenését a névszói esetrag jelentésszerkezetében, mivel a jelentés kiterjesztődése motivált az esetrag jelentéshálózatában.

\section{Módszertan}

Az itt bemutatott vizsgálati mód egy csoportosítási feladat. 25 anyanyelvi beszélőt kértem meg a feladat elvégzésére, mindegyikük valamilyen nyelvészeti vagy nyelvtanár szakos egyetemi hallgató, mester szintű diplomával nyelvészeti szakból senki nem rendelkezik. Mindegyik adatközlő mindegyik ragból 20 kártyán kapta meg a csoportosítandó nyelvi adatokat. A kártyákon pontosan egyszer szerepelt a kiválasztott raggal ellátott szó, az adott ragot pedig vastaggal szedtem. A mondatok egyszerűsített korpuszadatok voltak, és egy előzetes vizsgálat során válogattam ki őket, ennek módját l. a 3.1.-ben.

\subsection{Az előzetes korpusz alapú vizsgálat}

Az előzetes vizsgálathoz a Magyar Nemzeti Szövegtár adatbázisát használtam (v2.0.5.; I. Oravecz-Váradi-Sass 2014). A korpuszban olyan névszókra kerestem, amelyek az adott esetalakban szerepelnek. Ebből azután véletlenszerüen rendezett listákat hívtam le: a -nak/-nek raggal 500 tokenes véletlen listát (mivel a kutatás fő fókusza ez volt), a -hoz/-hez/-höz és a -nál/-nél raggal pedig 100-100 tokenes véletlen listát, az ismétlődő adatokat kiszűrtem. Ezeket az adatokat kézzel elemeztem aszerint, hogy az adott raggal szereplő névszó milyen funkciót tölt be a saját konstrukciójában. Ehhez megvizsgáltam a szövegszók szövegkörnyezetét, és megnéztem, milyen viszonyok kidolgozásában vesznek részt a ragos névszók. Ezáltal kiderült, hogy az egyes funkciók milyen gyakorisággal fordulnak elő a korpuszban.

A korpuszvizsgálatra azért is volt szükség, mert szerettem volna biztosítani, hogy minden funkciónak szerepeljen legalább egy azt képviselő mondata a kártyákon, 
illetve szerettem volna kikerülni, hogy bármelyik funkció (ezen az egy, biztosított kártyán túl) alul vagy felül legyen reprezentálva. A korpuszban megjelenő funkciók mellett a szakirodalom (vö. Rácz-Szemere 1985; Keszler 2000) listáit is áttekintettem, így ha a véletlen listában nem is fordult elő egy funkció, a kártyák közé innen bekerült. Az 1-3. táblázat bemutatja a ragok jelentéshálózatában az előzetes vizsgálat során elkülönített funkciókat a véletlen listában megjelenő előfordulási arányukkal. A csillaggal $\left(^{*}\right)$ jelöltek a véletlen listában nem fordultak elő.

Az 1. táblázat a -nak/-nek ragos névszó által betöltött funkciókat listázza a gyakoriságukkal együtt. Minden funkció alatt feltüntettem egy jellemző mondatot, ezekben a -nak/-nek ragot a kártyákon megjelenített módhoz hasonlóan vastagon szedtem.

\begin{tabular}{|c|c|}
\hline Funkció & $\begin{array}{l}\text { Előfordulási } \\
\text { arány }\end{array}$ \\
\hline $\begin{array}{l}\text { vmivel összetartozás (hagyományosan genitívusz): } \\
\text { •A fiúnak a könyve került hozzám. }\end{array}$ & $41 \%$ \\
\hline $\begin{array}{l}\text { egy (tranzakciós) folyamat térbeli végpontja úgy, hogy a -nak/-nek } \\
\text { ragos névszó egy mozgatott tárgy recipiense; illetve egy folyamat } \\
\text { kedvezményezettje vagy kárvallottja (hagyományosan datívusz): } \\
\text { •A diákoknak kiosztották a félévi bizonyítványt. }\end{array}$ & $25 \%$ \\
\hline $\begin{array}{l}\text { mentális folyamat, kiértékelés végpontja } \\
\text { •János festönek kiváló. }\end{array}$ & $13 \%$ \\
\hline $\begin{array}{l}\text { a hagyományos datívusz és genitívusz közötti átmenetek: } \\
\text { 1. datívusz posszesszívusz: } \\
\text { •Vége a hangoskodásnak. } \\
\text { 2. birtokos részeshatározó: } \\
\text { •A bizottságnak egy hónap áll rendelkezésére. }\end{array}$ & $8,6 \%$ \\
\hline $\begin{array}{l}\text { egy folyamat ágense/experiense: } \\
\text { •Az alperesnek fizetnie kell. }\end{array}$ & $5,4 \%$ \\
\hline $\begin{array}{l}\text { egy jelenet, esemény (motiváló) okának kifejezése: } \\
\text { •Mi mindig örülünk egymásnak. }\end{array}$ & $3,8 \%$ \\
\hline $\begin{array}{l}\text { mozgásos folyamat végpontjának, irányának kifejezése: } \\
\text { •A szörfös a parti köveknek csapódott. }\end{array}$ & $1,4 \%$ \\
\hline $\begin{array}{l}\text { egy folyamat által bekövetkezett eredményállapot kifejezése: } \\
\text { •A nagymamám a málnát szörpnek teszi el. }\end{array}$ & $0,8 \%$ \\
\hline $\begin{array}{l}\text { *etikai datívusz: egy diszkurzív jelenetben való belső érintettség } \\
\text { kifejezése: } \\
\text { •Csak le ne verjen nekem valamit! }\end{array}$ & - \\
\hline
\end{tabular}

1. táblázat

A -nak/-nek ragos névszók funkciói a korpuszban a véletlen minta alapján

A táblázathoz az alábbi megjegyzéseket érdemes tenni. Egyrészről az egyes kategóriákat funkciók alapján különítettem el elsődlegesen, mégis nyilvánvaló, hogy bizonyos kategóriák ehhez járuló konstrukciós sémái strukturálisan sajátosak. A datívusz posszesszívusz szerkezet alaptagja például a birtoklást kifejező van/nincs ige, amely vonzata a -nak/-nek ragos névszó. A birtokos részeshatározó olyan szerkezet, amelyben a birtokos és a birtoktárgy közötti személybeli egyeztetés morfológiailag 
is kidolgozásra kerül a birtokos személyjel által, a -nak/-nek ragos névszó által kifejezett szereplő pedig egyszerre értelmezhető a folyamat kedvezményezettjeként (vagy kárvallottjaként), illetve birtokosként is (vö. Elekfi 1993). A birtokos részeshatározó a datívuszi viszonyhoz áll közelebb szemantikailag, mivel a jelenet kedvezményezettjeként is feldolgozható a -nak/-nek ragos névszó a szerkezetben, míg a datívusz posszesszívusz a genitívuszi viszonyhoz áll közelebb: birtoklást fejez ki.

A hagyományos értelemben vett genitívuszi viszonyokat nem válogattam külön, egységesen összetartozási viszonyként kezeltem őket (vö. Hadrovics 1969: 139177). Szintén sajátos az etikai datívusz esete, amely jellemzően az egyes szám első személyü, datívuszi esetalakban álló személyes névmási formában (nekem) fordul elő, így ebben az esetben nem lehetett ragos névszóként szerepeltetni a kártyán.

Láthatjuk azt is, hogy a jelentésszerkezet két nagyobb csomópontját a hagyományos értelemben vett genitívuszi és datívuszi viszonyok adják. A magyar morfológiai kutatásokban él az a vita, hogy a birtokos viszony beletartozik-e a -nak/-nek rag poliszém jelentéshálózatába, vagy ebben az esetben már homonímiát érdemes feltételezni (vö. Ladányi 2008; 2017). ${ }^{4}$ A homonímiát támogatják a többi viszonytól való jellegzetes strukturális eltérések: ez az egyetlen olyan szerkezettípus, amelyben a -nak/-nek ragos névszó minden esetben egy másik névszónak van alárendelve, illetve a viszony a szerkezet fején is jelölve van, a birtokos személyjel által (Ladányi 2008: 533). Azonban a poliszémia melletti érv lehet az, ha az adatközlők a feldolgozás módjában analógiát éreznek, valamint ha az átmeneti jelentések (birtokos részeshatározó és datívusz posszesszívusz) egyik vagy másik csoporthoz közelebb kerülnek majd a klaszteranalízisben.

A 2. táblázat a -hoz/-hez/-höz rag korpuszban előforduló funkcióit szemlélteti.

\begin{tabular}{|c|c|}
\hline Funkció & $\begin{array}{l}\text { Elöfordulási } \\
\text { arány }\end{array}$ \\
\hline $\begin{array}{l}\text { vmivel való összetartozás kifejezése: } \\
\qquad \text { •Az agave a liliomok családjához kapcsolódik. }\end{array}$ & $22 \%$ \\
\hline $\begin{array}{l}\text { absztrakt végcél kifejezése: } \\
\text { •A háztartások alkalmazkodtak a valósághoz. }\end{array}$ & $22 \%$ \\
\hline $\begin{array}{l}\text { folyamat konkrét térbeli céljának kifejezése: } \\
\text { •Nórát az ügyfélszolgálathoz irányítják. }\end{array}$ & $18 \%$ \\
\hline $\begin{array}{l}\text { folyamat elvont térbeli céljának kifejezése: } \\
\text { •A szervezet eddig csak egyszer fordult bírósághoz. }\end{array}$ & $17 \%$ \\
\hline $\begin{array}{l}\text { mentális folyamat vagy kiértékelés végpontjának kifejezése: } \\
\text { •A régebbi LG mobilhoz képest meglehetősen furcsán } \\
\text { néz ki az új. }\end{array}$ & $16 \%$ \\
\hline $\begin{array}{l}\text { konkrét végcél kifejezése: } \\
\qquad \text { Az alapítványhoz minimum tíz fő kellene. }\end{array}$ & $3 \%$ \\
\hline $\begin{array}{l}\text { egy folyamat címzettjének (recipiensének) kifejezése: } \\
\text { •A tévémúsor az idősebbekhez szól. }\end{array}$ & $1 \%$ \\
\hline
\end{tabular}

2. táblázat

A -hoz/-hez/-höz ragos névszók funkciói a korpuszban a véletlen minta alapján

${ }^{4}$ A kérdés vizsgálatához generatív grammatikai keretben vö. még Szabolcsi (1992). 
A 3. táblázat a -nál/-nél ragos névszók funkcióit mutatja be. Itt is volt a szakirodalomban listázott, de a véletlen mintában nem szereplő funkció, ezt most is csillag $\left.{ }^{*}\right)$ jelöli.

\begin{tabular}{|c|c|}
\hline Funkció & $\begin{array}{l}\text { Előfordulási } \\
\text { arány }\end{array}$ \\
\hline $\begin{array}{l}\text { vmivel való összetartozás kifejezése: } \\
\text { •Zsuzsa egy televíziós cégnél dolgozik. }\end{array}$ & $22 \%$ \\
\hline $\begin{array}{l}\text { konkrét térbeli pont kifejezése: } \\
\text { •Csak öt percig maradtam anyámnál. }\end{array}$ & $20 \%$ \\
\hline $\begin{array}{l}\text { vmivel való összehasonlítás kifejezése: } \\
\text { •A számlám a vártnál lényegesen magasabb. }\end{array}$ & $19 \%$ \\
\hline $\begin{array}{l}\text { idő/alkalom kifejezése: } \\
\text { •Az ír teniszezó 6:0, 5:1-nél feladta a meccset. }\end{array}$ & $19 \%$ \\
\hline $\begin{array}{l}\text { absztrakt térbeli pont kifejezése: } \\
\text { •Néhány szervezetnél lassabban mennek a dolgok. }\end{array}$ & $14 \%$ \\
\hline $\begin{array}{l}\text { hely / külső állapot kifejezése: } \\
\text { •Marianna a konyhában ült gyertyafénynél. }\end{array}$ & $2 \%$ \\
\hline $\begin{array}{l}\text { tekintet / szempont kifejezése: } \\
\text { •A színészeknél Dr. House karaktere a legnépszerübb. }\end{array}$ & $2 \%$ \\
\hline $\begin{array}{l}\text { *állapot kifejezése: } \\
\text { •A sérült férfi öt percig nem volt tudatánál. }\end{array}$ & - \\
\hline
\end{tabular}

3. táblázat

A -nál/-nél ragos névszók funkciói a korpuszban a véletlen minta alapján

Az eredményekből érdemes megjegyezni, hogy a prototípusként elgondolt, konkrét térbeli viszonyokat kifejező jelentések a -hoz/-hez/-höz és a -nál/-nél ragnál valóban dominánsak, viszont a -nak/-nek rag esetében az egyik legkevesebbszer elöforduló funkció volt ez. Ami miatt prototípusként érdemes számolni vele mégis, az az, hogy ez szolgáltatja a kognitív motivációt a jelentés kiterjesztésében.

\subsection{A csoportosítási feladat}

A csoportosítási feladat mintáját Sandra és Rice (1995) kísérlete adta, akik az angol in, over és at prepozíciókkal végeztek hasonló vizsgálatot. Ök is $20-20$ kártyát használtak stimulusként, a kezelhetősége miatt ezt a számot megtartottam a kísérlet során, viszont az a módszer, ahogy kiválasztottam a példamondatokat a kártyákra, különbözik az eredetitől. Sandra és Rice előhívásos tesztet végeztettek egyetemistákkal: a mondatoknak tartalmaznia kellett az adott elöljárószót; majd ezek közül választottak ki véletlenszerüen 20-at a kártyákra.

A mostani kísérlethez először is biztosítottam, hogy az 1-3. táblázatokban bemutatott funkciók legalább egy kártyán szerepeljenek. A fennmaradó helyekre pedig egy funkciók szerint reprezentatív mintából választottam véletlenszerűen. Az így összeállított 20 kártyának az elején szerepeltek az egyszerǔsített MNSZ-mondatok, amelyekben a vizsgált esetrag vastaggal volt szedve. A kártyák hátulján a lejegyzést segítő kódszám szerepelt, ezt azonban az adatközlők nem látták. Minden adatközlö mindhárom sorozatot megkapta. Az adatközlők véletlen sorrendben kapták meg a 
paklikat is, és azokon belül is kevert sorrendben voltak a kártyák: a sorrend tehát nem lehetett az eredményt befolyásoló tényező. A feladatnak időkorlátja nem volt, az utasítást a feladat közben mindvégig látták az adatközlők. Ez a következő volt:

(1) Rendezze a kártyákat tetszőleges számú csoportba aszerint, hogy a $[X]^{5}$ rag milyen jelentésben szerepel az adott mondatban!

A feladat szövegéből szándékosan voltak kihagyva olyan nyelvészeti terminusok, mint funkció, viszony vagy eset. Az adatközlők tetszőleges számú csoportot hozhattak létre az egyes sorozatokból. Az eredményeket a csoportosítás után számosítottam, Past szoftverrel lejegyeztem, a szoftver az adatokon hierarchikus klaszteranalízist végzett, ennek az eredményét pedig dendrogramon ábrázolta. A dendrogram azt mutatja meg, hogy a 25 adatközlő szerint melyek azok a jelentések, amelyek közelebb állnak egymáshoz, és melyek azok, amelyek távolabb vannak egymástól. Ezt az ábrázolási módot Divjak és Gries (2008) a poliszém jelentéshálózat sugaras elrendeződéséhez hasonlítják. A -nak/-nek rag dendrogramját az 1. ábra szemlélteti.

A gráf $X$ tengelyén a számok a kártyák kódszámát jelentik (a közölt nyelvi adatoknál a továbbiakban ezeket \#-tel jelölöm). Az Y tengely Similarity 'hasonlóság' felirata pedig arra utal, hogy onnan olvashatjuk le, milyen valószínűséggel csoportosították egybe az egyes kártyákat az adatközlők, ez az érték 0-tól 1-ig terjedhet. Az ábrát alulról felfelé kell értelmezni, a szétváló ágak jelzik az elkülönüléseket: minél lejjebb válik szét a gráf egyik ága, annál távolabb állnak a jelentések egymástól. Kétféle szélsőséges forgatókönyv lett volna lehetséges: ha a beszélők minden kártyából önálló csoportot alkottak volna, akkor 20 különálló ágat láthatnánk; amennyiben pedig egyetlen csoportot hoztak volna létre a 20 kártyából, akkor az Y tengely tetején látnánk egyetlen vízszintes csíkot.

\section{Eredmények}

Az általános statisztikai eredményeket a 4. táblázat mutatja:

\begin{tabular}{|l|c|c|c|}
\hline & -nak/-nek & -hoz/-hez/-höz & -nál/-nél \\
\hline $\begin{array}{l}\text { legkevesebb-legtöbb } \\
\text { létrehozott csoport }\end{array}$ & $2-11$ & $2-11$ & $3-10$ \\
\hline $\begin{array}{l}\text { adatközlönkénti átlagos } \\
\text { csoportszám }\end{array}$ & 6,4 & 5,4 & 5,7 \\
\hline $\begin{array}{l}\text { leggyakoribb } \\
\text { csoportszám }\end{array}$ & 6 & 4 & 5 \\
\hline $\begin{array}{l}\text { legkisebb elemszám / } \\
\text { csoport }\end{array}$ & 1 & 1 & 1 \\
\hline $\begin{array}{l}\text { legnagyobb elemszám / } \\
\text { csoport }\end{array}$ & 17 & 17 & 12 \\
\hline
\end{tabular}

4. táblázat

A csoportosítás utáni eredmények

${ }^{5}$ Mindegyik sorozatnál látható volt ez a szöveg, az $[X]$ helyén az adott rag szerepelt vastaggal szedve. 
Az eredmények után több dolgot is érdemes megvizsgálni. Az egyik ilyen a szétválási pontok helyzete. Minél lejjebb válik szét két csoport, annál jobban elkülönülnek, vagyis az elemeiket kevesebb adatközlő tette egy csoportba. Kulcsfontosságú a legalsó szétválási pont: minél magasabb értéknél helyezkedik el a legalsó szétválási pont, feltehetően annál nehezebb volt az adatközlők számára a disztinkt csoportok létrehozása. A legfelső szétválási pont azt mutatja meg, hogy az egymáshoz legközelebb álló jelentések mennyire szorosak. Általánosságban: minél alacsonyabban válik el egy ág egy másik ágtól, annál markánsabb a köztük lévő jelentésbeli különbség. Az 1-3. ábrán látható a három esetrag dendrogramja.

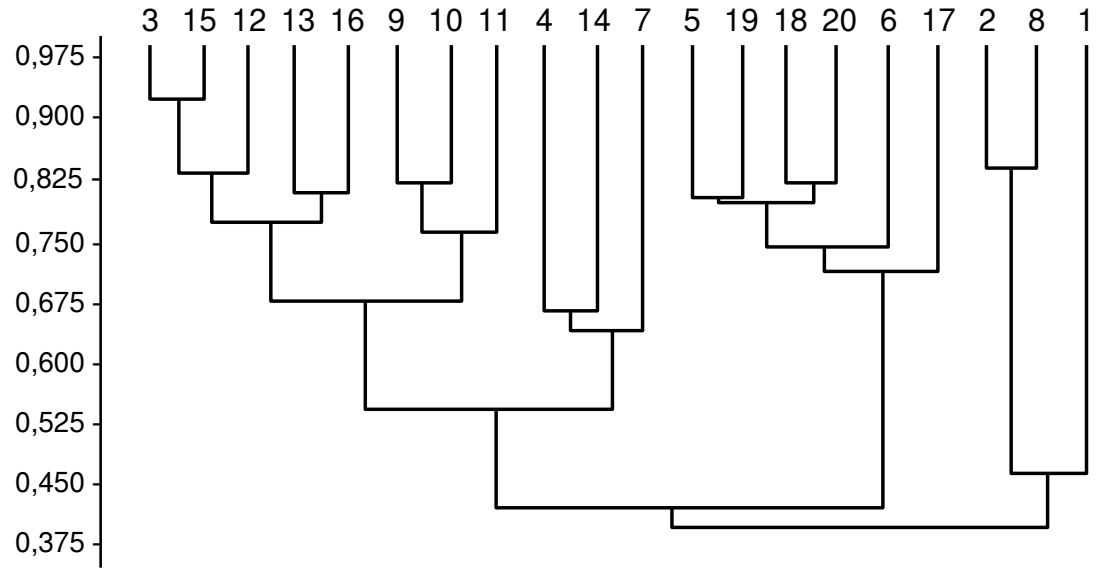

1. ábra

A -nak/-nek rag dendrogramja

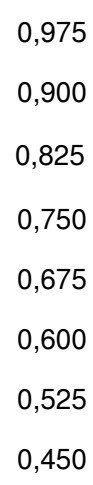

2. ábra

A -hoz/-hez/-höz rag dendrogramja 


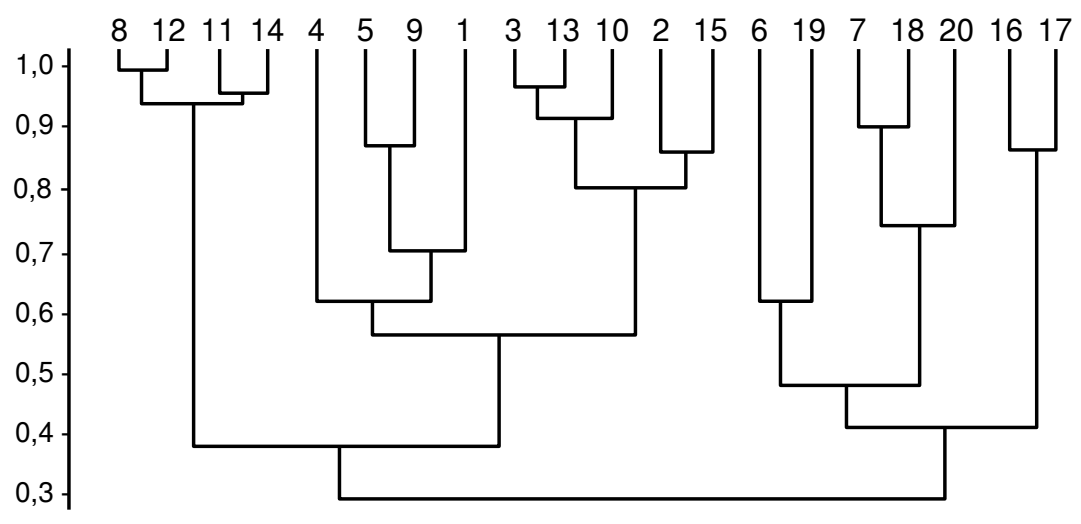

3. ábra

A -nál/-nél rag dendrogramja

A három gráf legalsó szétválási pontjai kapcsán az alábbiakat láthatjuk. A legalacsonyabban a -nál/-nél rag ábráján van ez a pont, 0,3-as értéknél. Ez azt jelenti, hogy a leginkább elkülönülő jelentéscsoportok ennél a ragnál jöttek ki. Ezt támasztja alá az is, hogy a leginkább összetartozó elemek (\#8, \#12) az 1-es értékhez közel válnak szét. Ez azt is valószínüsíti, hogy itt érezték az adatközlők a legkönnyebbnek azt a feladatot, hogy különálló csoportokat kell létrehozniuk. A legmagasabban a -hoz/-hez/-höz rag ábráján van az első szétválási pont: 0,45-nél. Az egymáshoz legközelebb álló két jelentés itt válik el a legkisebb értéknél: 0,9-nél. Az adatközlők számára tehát valószínüleg ennél a ragnál volt a legnehezebb csoportokat elkülöníteni.

Ezeket a feltételezéseket erősíteni látszik az adattábla is. A számosított adatokból ki lehet olvasni, hogy melyek azok a kártyák, amelyeket egyik adatközlő sem sorolt ugyanabba a csoportba. Sokatmondó tehát az is, hány olyan párosítás van, amelyet senki nem érzett összetartozónak. Ennek a számnak a nagysága szintén a jelentések nagyobb fokú elkülönülését mutatja. Ez az adat a fentebbiekkel összefüggő képet mutat. A -nál/-nél rag esetében fordult elő a legtöbb olyan párosítás, amelyet egyetlen adatközlő sem érzett összetartozónak: összesen 27. A legkevesebb ilyen pedig a -hoz/-hez/-höz ragnál volt: mindössze 3 . Vagyis az előbbinél jobban szétváltak a jelentések, mint az utóbbinál.

Az adattáblából azt is meg tudjuk nézni, hogy melyek azok a kártyák, amelyeket a legkevesebb további kártyával soroltak egy csoportba az adatközlők. Ez arról árul el valamit, hogy melyik megvalósulást érezték jelentéstanilag a legkevésbé hasonlónak a többi megvalósuláshoz. Az ilyen adatoknál valószínüsíthetünk egy önálló jelentést.

A -nál/-nél rag adatai közül az alábbi két kártyát sorolták együtt a legkevesebbszer más kártyákkal egy csoportba:

(2) \#7 Az ír teniszező 6:0, 5:1-nél feladta a meccset.

(3) \#18 Az énekes az élő adások felénél kiesett a versenyből. 
Ezek az általam felálított csoportok közül az „idő / alkalom” csoportba tartoznak. A 3. ábráról leolvasható, hogy ezek egy ágon helyezkednek el a gráfon. Vagyis egymáshoz közel, a többi jelentéstől viszont viszonylag távol kerültek.

A -nak/-nek rag datívuszi sürűsödési tartományában az a kártya, amelyet a legkevesebb további kártyával soroltak egy csoportba, az etikai datívusz kártyája volt:

$$
\text { \#7 Csak le ne verjen nekem valamit! }
$$

Ez több szempontból is különleges példa, erről részletesebben I. a 4.1-es részt. Ahogy az 1. ábra mutatja, ez a kártya két másikkal került közeli ágra:

(5) \#4 Mi mindig örülünk egymásnak.

(6) \#14 Az ügy nagyon fontos önnek. ${ }^{6}$

A (4)-(6) egy csoportba tartozását motiválhatta az, hogy ezekben a mondatokban a -nak/-nek rag által megkonstruált szereplő a folyamatban belsőleg érintett. A következőkben az egyes ragok vizsgálatának eredményeit részletezem.

\subsection{A -nak/-nek rag}

A vizsgálat fókuszában a -nak/-nek rag jelentésszerkezete állt, a másik két rag adatai bizonyos összevetéseket tesznek lehetővé. Az előzetes korpuszvizsgálat a jelentésszerkezetben két nagyobb csomópontot mutatott ki: a datívuszi és genitívuszi funkciókat. A dendrogram (I. 1. ábra) három fő ágat mutatott: a datívuszi és a genitívuszi funkciók csoportja mellett a „kivételes” jelentések csoportját. Azok a jelentések, amelyek egymáshoz a legközelebb álltak, a recipiensi funkció megvalósulásai voltak:

(7) \#3 A diákoknak kiosztották a félévi bizonyítványt.

(8) \#15 A hallgató levelet írt a professzornak.

Ezek olyan jelenetet írnak le, amely egy fizikai térben elképzelhető tranzakciós folyamatként. A szereplők olyan személyek, akik egy fizikai tárgyat eljuttat(hat)nak egy másik személyhez, a recipienshez, amelyet a -nak ragos névszók dolgoznak ki. Ezekhez legközelebb a kedvezményezettet/kárvallottat kidolgozó -nak/-nek ragos névszókat tartalmazó kártyák voltak.

(10) \#13 A világbajnokságon az olaszoknak drukkoltam.

(11) \#16 Zsófi egy életmódmagazinnak dolgozik.

A datívuszi csomóponton belül egy további alcsoportot is találunk. Ez azoknak a mondatoknak a csoportja, amelyek deontikus modalitásúak. A deontikus modalitás kötelezettséget fejez ki (vö. Talmy 2000). A magyarban a deontikus modalitású konstrukció egy tipikus sémája a kell igét tartalmazza, amely a szükségességet folyamatként konstruálja meg, a szükséges folyamat pedig főnévi igenévként kerül kidolgozásra. Az erő/elvárásrendszer a -nak/-nek ragos szereplöre hat (vö. Kugler 2017:

${ }^{6}$ Köszönöm a tanulmány egyik anonim lektorának, hogy felhívja a figyelmet arra, hogy a (4)-(6) mondatokban a -nak/-nek rag mind névmásokra kerül. A tanulmány a későbbiekben több ponton is reflektál arra, hogy egyes mondatok egy ágra kerülését a szerkezeti hasonlóságok is motiválhatják. A (4)-(6) példákban a szófajiság mellett viszont szemantikai összefüggést mutat az is, hogy mind személyt (a szituáció résztvevőjét) jelölő névmások. 
481-482). A deontikus alcsoportot mutatják a (12)-(13) mondatok, amelyekkel a (14) is egy ágra került:

(12) \#9 Idegeneknek belépni tilos.

(13) \#10 Az alperesnek fizetnie kell.

(14) \#11 A bizottságnak egy hónap áll rendelkezésére.

Azt, hogy ezek a kártyák a datívuszi ágba kerültek, motiválja az, hogy a -nak/-nek ragos névszók által jelölt szereplők a folyamat belső érintettjei. Ez alapján kerülhet ide az etikai datívusz is:

\section{\#7 Csak le ne verjen nekem valamit!}

Ez a szerkezet azért is különleges, mert a többi mondathoz képest ebben szigorú értelemben véve nem ragként jelenik meg a -nak/-nek. Az etikai datívusz a magyarban általában az egyes szám első személyű személyes névmás datívuszi esetalakjában jelenik meg (Rácz-Szemere 1985: 86). Más nyelvekben is jellemzően névmási alakokban fordul elő ez a funkció, a cseh nyelvben az egyes szám második személyű személyes névmáson. Fried (2014: 13) szerint ez az etikai datívusz diskurzusépítő funkciója miatt lehet. Az ilyen típusú datívusz funkciója főként pragmatikai (Janda 1993: 89), a beszédszituációba erősen beágyazott. Emiatt Fried (2014: 12-13) az 'interakciós datívusz' elnevezést javasolja az etikai datívusz helyett.

A -nak/-nek rag dendrogramjának egy másik nagy ága a genitívuszi funkcióknak az ága. Ide tartozik az elidegeníthető birtokosság, amikor a birtokos tipikusan humán szereplő, akinek a birtokában egy fizikai tárgy van (16), a (17)-(20) példák pedig absztraktabb összetartozási viszonyokat dolgoznak ki:

(16) \#5 A fiúnak a könyve került hozzám.

(17) \#19 A vállalkozóknak egy széles rétege pályázhat.

(18) \#18 A testület ura a helyzetnek.

(19) \#20 Az eszmecserének az időpontját október 15-re javasoljuk.

(20) \#17 Vállára borulhatsz az édesanyádnak.

Az itt felsorolt példák a tipikus birtokláson kívül többfajta összetartozási viszonyt tesznek kidolgozottá. A -nak/-nek ragos névszók szemantikai struktúrájából a figyelem előterébe kerülhet: a) az egész egy része (17); b) hogy valami hatalmat gyakorol valami más felett (18); c) egy esemény időpontja (19); d) egy személy egy testrésze (20).

A (16)-(20)-as mondatokban a -nak/-nek ragos névszók szerkezetileg egy névszói fejnek vannak alárendelve, ez pedig különbözik a további -nak/-nek ragos konstrukcióktól. Ahogy a tanulmány korábban említette, ennél a funkciónál felmerül annak a gyanúja, hogy itt a -nak/-nek egy homonim változatával találkozunk. Ennek a vitának az eldöntésében segíthet az is, hogy az adatközlők hová sorolták a datívusz és genitívusz közötti átmeneteket.

A birtokos részeshatározó a datívuszi funkcióhoz áll közelebb: a -nak/-nek ragos névszó egy ige bővítménye, és feldolgozható egy szituáció kedvezményezettjeként vagy kárvallottjaként, de egyeztetve van egy birtokos személyjeles névszóval személyben. A datívusz posszesszívusz a genitívuszi funkcióhoz áll közelebb: a -nak/-nek ragos névszó a birtoklást kifejező (kifejtett vagy kifejtetlen) van/nincs ige bővítménye, és szintén egyeztetve van személyben egy birtokos személyjeles névszóval. 
A birtokos részeshatározó (21) valóban a datívuszi csomópontba került, míg a datívusz posszesszívusz (22) a genitívusziba:

(21) \#11 A bizottságnak egy hónap áll rendelkezésére.

(22) \#6 Vége a hangoskodásnak.

Ez azt jelenti, hogy az adatközlők analógiákat éreztek ezek és a további datívuszi/genitívuszi funkciók jelentéseinek feldolgozásában.

A harmadik nagy ágba három, ezektől eltérő jelentésü funkció került. Eléggé elkülönülve, minden mástól alacsony Y-értéknél elválva jön a téri viszony kifejezése (23). A mentális folyamat, kiértékelés végpontjának kidolgozása (24) és az eredményállapot kifejezése (25) viszont egymáshoz közel kerültek a dendrogramon. A (23)(25) viszont a datívuszi és genitívuszi csomóktól jellemzően elkülönülnek.

(23) \#1 A szörfös a parti köveknek csapódott.

(24) \#8 János festónek kiváló.

(25) \#2 A nagymamám a málnát szörpnek teszi el.

A dendrogramon (I. 1. ábra) tehát három nagy jelentéscsoport különül el. Az egyik a datívuszi, a másik a genitívuszi, a harmadik pedig az ezektől eltérő funkciók csoportja. Az eredmények segítenek abban, hogy lássuk: a datívuszi és a genitívuszi funkciók jelentéstanilag is összefüggnek, a közöttük lévő átmeneti jelentések elhelyezkedése pedig arra enged következtetni, hogy a jelentés kiterjesztése az eredeti, helyviszonyjelöléstől a datívuszi funkciókon keresztül a genitívusziig motivált.

\subsection{A -hoz/-hez/-höz rag}

Elsődlegesen ez is helyviszonyt konstruál meg. A kártyák között egyetlen olyan volt, amelyben a rag egy névutói konstrukcióban jelenik meg (26): a vmihez képest ragvonzó névutó névszóján. $A$ 2. ábrán látszik, hogy ez a szerkezet az összes többitől elválik, ráadásul nagyon alacsony Y-értéknél. A névutós konstrukció egyszerre különült el strukturálisan is a további konstrukcióktól, valamint a szerkezet nagyfokú szemantikai absztraktsága is oka lehetett annak, hogy ennyire eltávolodik a gráfon a többi adattól.

(26) \#18 A régebbi LG mobilhoz képest meglehetősen furcsán néz ki az új.

Továbbá a 20 kártya közé két olyan is került, amelyben a -hoz/-hez/-höz ragos névszó a köt 'kapcsolódik' ige egy-egy származékának vonzataként fordul eló. Ezekben az esetekben a szemantikai különbözőség azonban „felülírta” a strukturális hasonlóságokat. A \#15-ös mondat hamar különválik a többi mondattól, a \#11-es azonban további, összetartozást kifejező funkciójú ragokat tartalmazó mondatokkal került egy csoportba (I. (27)-(30)).

(27) \#15 Pályázni csak határidőhöz kötötten lehet.

(28) \#11 A szervezetek pártokhoz egyáltalán nem kötődnek.

(29) \#12 Az agave a liliomok családjához kapcsolódik.

(30) \#20 Az úri társasághoz tartozás nem volt kedvemre való.

Hiába volt a struktúra hasonló a \#15-ös és a \#11-es mondat között, a 'valamihez tartozás' mint jelentés erősebb motivációnak bizonyult a csoportok létrehozásakor. 


\subsection{A -nál/-nél rag}

Ahogy a tanulmányban korábban szó volt róla, ennél a ragnál jöttek létre a leginkább elkülönülő csoportok. A \#8-as és a \#12-es mondatokat a 25-ből 24 adatközlő egy csoportba sorolta. Közel kerültek hozzájuk a \#11-es és a \#14-es is (I. 31-34):

(31) \#8 A színészeknél Dr. House karaktere a legnépszerübb.

(32) \#12 Gyermekeknél intő jel lehet a hirtelen súlyvesztés.

(33) \#11 Eltökéltségből nem volt hiány a kenusoknál.

(34) \#14 Sokaknál jelentkeztek a csontritkulás tünetei.

A (31)-(34)-ben közös az, hogy a -nál/-nél rag humán szereplőt kidolgozó névszókra kerül rá.

A 3. táblázatban felsorolt funkciók gyakoriságából látszik, hogy a valamivel való összehasonlítás funkciójának kifejezése az egyik legjellemzőbb. A kártyák közé 3 ilyen került, a \#4-es, \#16-os és \#17-es; ezek közül azonban csak az utóbbi kettő alkot egy csoportot (l. (35)-(36)):

(35) \#16 A számlám a vártnál lényegesen magasabb.

(36) \#17 A felelösök különbnél különb kritériumrendszereket állítanak föl.

A \#4-es mondat azonban a különféle helyviszonyokat kidolgozó példák közé sorolták be (I. (37)-(40)):

(37) \#4 Az autóbusz nem jutott Budapestnél messzebbre.

(38) \#5 Marianna a konyhában ült gyertyafénynél.

(39) \#9 A mikrofonnál Bőti Attila.

(40) \#1 Csak öt percig maradtam anyámnál.

A hasonlító szerkezet egyik tipikus konstrukciós sémája a -bb jeles középfokú melléknév (vagy határozószó), és egy -nál/-nél esetraggal ellátott névszó, amely kifejezi az összehasonlítottak közül azt a szereplőt, amelyikre az összehasonlítás alapja kevésbé jellemző. A Budapestnél messzebbre ennek a szerkezeti sémának megfelel, mégis másik csoportba került. Ez azért lehet, mert a -nél rag ebben az esetben egy olyan névszóra kerül, amely földrajzi névként (tulajdonnévként) a fizikai térben konkrét helyszínt jelöl ki. Így helyviszonyt kidolgozó szerkezetekkel kerülhetett egy csoportba. Ebben az esetben tehát annak a névszónak a jelentése, amelyre az esetrag került, nagymértékben befolyásolta a döntéshozatalt, illetve a jut ige is olyan folyamatot dolgoz ki, amely során valaki (valami) helyváltoztatást végez.

Az elemzések azt mutatják, hogy nem lehet pontosan tudni, hogy az anyanyelvi beszélők a csoportosítási feladat során a döntéseiket mi alapján hozták meg. Tudatosan nem kérdeztem meg a beszélőket a döntéseik okáról, ezzel akartam elkerülni, hogy túlságosan reflexívek, illetve önreflexívek legyenek a folyamat során. Így természetesen az sem tudható, hogy korábbi, oktatásban elsajátított ismereteik mennyiben befolyásolták őket a döntéshozatalban. Azt viszont láthatjuk, hogy a szerkezeti és a jelentésbeli hasonlóság egyaránt motiválta a csoportosítási döntéseket. 


\section{5. Összefoglalás}

A tanulmányban egy olyan empirikus kutatási módszert mutattam be, amelyet magyar nyelvi anyagon még nem használtak. A csoportosítási feladat segíthet abban, hogy az esetragok poliszémiáját egy újfajta nézőpontból lehessen vizsgálni: a nyelvhasználói intuíciók szerint. A kísérletben három esetragot vizsgáltam: a vizsgálat fő fókusza a -nak/-nek rag jelentésszerkezetének feltárása volt, de a -hoz/-hez/-höz és a -nál/-nél ragokkal is elvégeztem a kísérletet.

A módszer nagyobb megbízhatósága érdekében a mintául szolgáló kísérlet módszertanán több ponton változtattam. A kártyák kiválasztásához egy előzetes korpuszalapú vizsgálatot végeztem mind a három esetraggal, hogy az egyes funkcióik korpuszban előforduló gyakoriságát meg lehessen állapítani.

A csoportosítási feladat elvégzése után a számosított adatokból hierarchikus klaszteranalízissel dendrogramok készültek, amelyek megmutatják, milyen nagyobb csomópontokat lehet találni a jelentések között. Az összefüggőbb jelentések egy csoportot alkottak az ábrákon.

Az ábrák elemzése alapján a következők láthatók. A -nak/-nek rag jelentésszerkezetében a korpuszvizsgálathoz hasonlóan itt is két nagyobb csomópont rajzolódik ki: a datívuszi és a genitívuszi csomópontok. A kettő közötti átmeneti jelenségek: a datívusz posszesszívusz és a birtokos részeshatározó a nekik analogikusan megfelelő csomópontokba kerültek. Ez azt erősíti, hogy a genitívuszi funkció jelölése is a poliszém jelentésstruktúra része. A -hoz/-hez/-höz és a -nál/-nél ragok vizsgálatában láthattuk, hogy a jelentés mellett a strukturális sajátosságok szintén befolyásolhatják az eredményeket, még akkor is, ha a feladat jelentésbeli besorolást kért. Így előfordult olyan is, hogy a funkció szerinti besorolás az előzetes vizsgálatban más eredményt hozott, mint a nyelvhasználók saját intuíciói szerinti besorolás. A csoportosítási feladat közelebb vihet minket azokhoz a konceptuális struktúrákhoz, amelyek a nyelvhasználók jelentésképző folyamatait sémaként irányítják.

\section{Hivatkozások}

Cuyckens, Hubert - Britta Zawada 2001. Introduction. In Hubert Cuyckens - Britta Zawada (szerk.) Polysemy in Cognitive Linguistics. Selected papers from the International Cognitive Linguistics Conference, Amsterdam, 1997. (Current Issues in Linguistic Theory 177) Amsterdam, Philadelphia: John Benjamins Publishing Company. ix-xxvii. doi:10.1075/cilt.177.02cuy.

Divjak, Dagmar - Stefan Th. Gries 2008. Clusters in the mind?: Converging evidence from near synonymy in Russian. The Mental Lexicon 3/2:188-213. doi:10.1075/ml.3.2.03div.

Elekfi László 1993. Eltűnőben van-e a magyar birtokos részeshatározó? In Horváth Katalin - Ladányi Mária (szerk.) Állapot és történet - szinkrónia és diakrónia - viszonya a nyelvben. Budapest: ELTE BTK. 35-45.

Fried, Mirjam 2014. From semantic to interactional dative: a preliminary investigation. In Michaela Martinková - Markéta Janebová - Jaroslav Macháček (szerk.) Categories and Categorial Changes: The Third Syntactical Plan and Beyond. Olomouc: Palacký University. 12-20. 
Hadrovics László 1969. A funkcionális magyar mondattan alapjai. Budapest: Akadémiai Kiadó.

Janda, Laura A. 1993. A Geography of Case Semantics. The Czech Dative and the Russian Instrumental. Berlin, New York: Mouton de Gruyter.

Johnson, Mark 1987. The Body in the Mind. The Bodily Basis of Meaning, Imagination, and Reason. Chicago: University of Chicago Press.

Keszler Borbála 2000. A határozók. In Keszler Borbála (szerk.) Magyar grammatika. Budapest: Nemzeti Tankönyvkiadó. 428-449.

Korompay Klára 1991. A névszóragozás. In Benkő Loránd - E. Abaffy Erzsébet (szerk.) A magyar nyelv történeti nyelvtana I. A korai ómagyar kor és elôzményei. Budapest: Akadémiai Kiadó. 284-318.

Kövecses Zoltán - Benczes Réka 2010. Kognitív nyelvészet. Budapest: Akadémiai Kiadó.

Kugler Nóra 2017. Az evidencialitás és a modalitás. In Tolcsvai Nagy Gábor (szerk.) Nyelvtan. (A magyar nyelv kézikönyvtára) Budapest: Osiris Kiadó. 467-494.

Ladányi Mária 2008. Van-e genitívusz a magyarban? In Bereczki András Csepregi Márta - Klima László (szerk.) Ünnepi írások Havas Ferenc tiszteletére. (Uralisztikai Tanulmányok 18) Budapest: ELTE BTK Finnugor Tanszék, Numi-Tórem Finnugor Alapítvány. 522-534.

Ladányi Mária 2017. Alaktan. In Tolcsvai Nagy Gábor (szerk.) Nyelvtan. (A magyar nyelv kézikönyvtára) Budapest: Osiris Kiadó. 503-662.

Lakoff, George 1987. Women, Fire, and Dangerous Things. Chicago, London: University of Chicago Press.

Langacker, Ronald W. 1987. Foundations of Cognitive Grammar: Vol. 1. Theoretical Prerequisites. Stanford: Stanford University Press.

Langacker, Ronald W. 2008. Cognitive Grammar. A Basic Introduction. Oxford, New York: Oxford University Press.

Lewandowska-Tomaszczyk, Barbara 2007. Polysemy, prototypes, and radial categories. In Dirk Geeraerts - Hubert Cuyckens (szerk.) The Oxford Handbook of Cognitive Linguistics. Oxford: Oxford University Press. 139-169.

Oravecz, Csaba - Tamás Váradi - Bálint Sass 2014. The Hungarian Gigaword Corpus. In Nicoletta Calzolari - Khalid Choukri - Thierry Declerck - Hrafn Loftsson - Bente Maegaard - Joseph Mariani - Asuncion Moreno - Jan Odijk - Stelios Piperidis (szerk.) Proceedings of the Ninth International Conference on Language Resources and Evaluation (LREC'14). Reykjavik: European Language Resources Association (ELRA). 1719-1723.

Pomázi, Bence 2019. An empirical method to distinguish the meanings of three case suffixes in Hungarian. Język. Komunikacja. Informacja 14:33-52.

Rácz Endre - Szemere Gyula 1985. Mondattani elemzések. Budapest: Tankönyvkiadó.

Radden, Günter - Klaus-Uwe Panther 2004. Introduction: Reflexions of motivation. In Klaus-Uwe Panther - Günter Radden (szerk.) Studies in Linguistic Motivation. Berlin, New York: Mouton De Gruyter.

Rosch, Eleanor H. 1973. Natural categories. Cognitive Psychology 4/3:328-350. doi:10.1016/0010-0285(73)90017-0. 
Sandra, Dominiek - Sally Rice 1995. Network analyses of prepositional meaning: Mirroring whose mind - the linguist's or the language user's? Cognitive Linguistics 6/1:89-130. doi:10.1515/cogl.1995.6.1.89.

Szabolcsi Anna 1992. A birtokos szerkezet és az egzisztenciális mondat. Budapest: Akadémiai Kiadó.

Talmy, Leonard 2000. Toward a Cognitive Semantics Vol 1. Concept Structuring Systems. Cambridge: The MIT Press.

Tolcsvai Nagy Gábor 2013. Bevezetés a kognitív nyelvészetbe. Budapest: Osiris Kiadó.

Tolcsvai Nagy Gábor (szerk.) 2017a. Nyelvtan. (A magyar nyelv kézikönyvtára) Budapest: Osiris Kiadó.

Tolcsvai Nagy Gábor 2017b. Jelentéstan. In Tolcsvai Nagy Gábor (szerk.)

Nyelvtan. (A magyar nyelv kézikönyvtára) Budapest: Osiris Kiadó. 207-502.

\section{A szerzőről}

Pomázi Bence az Eötvös Loránd Tudományegyetem Nyelvtudományi Doktori Iskolájának utolsó éves doktorandusza a Magyar nyelvészet program Leíró nyelvészet alprogramján. Az ELKH Nyelvtudományi Kutatóközpont Lexikológiai Intézetének tudományos segédmunkatársa.

Elérhetősége: pomazi.bence@gmail.com 